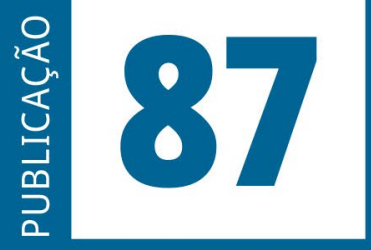

ISSN: 0101-9562

ISSN ELETRÔNICO: 2177-7055

SEQÜENCIA

Publicação do

Programa de Pós-Graduação em Direito da UFSC

VOLUME 42 - ANO 2021
Estudos jurídicos e políticos 
SEQUÊNCIA - ESTUDOS JURÍDICOS E POLÍTICOS é uma publicação temática e de periodicidade quadrimestral, editada pelo Programa de Pós-Graduação Stricto Sensu em Direito da Universidade Federal de Santa Catarina - UFSC.

SEQUÊNCIA - ESTUDOS JURÍDICOS E POLÍTICOS is a thematic publication, printed every four months, edited by the Program in law of the Federal University of Santa Catarina - UFSC.

Versão eletrônica: http://www.periodicos.ufsc.br/index.php/sequencia

A publicação é indexada nas seguintes bases de dados e diretórios/

The Publication is indexed in the following databases and directories:

Base OJS

Base PKP

CCN (Catálogo Coletivo Nacional)

Dialnet

DOAJ (Directory of Open Access Journals)

EBSCOhost

Genamics Journalseek

ICAP (Indexação Compartilhada de Artigos de Periódicos)

Latindex

LivRe!

OJS
PKP
Portal de Periódicos UFSC
Portal do SEER
ProQuest
SciELO
Sherpa/Romeo
Sumarios.org
ULRICH'S
vLex

Ficha catalográfica

Seqüência: Estudos jurídicos e políticos. Universidade Federal de Santa Catarina.

Programa de Pós-Graduação em Direito. n.1 (janeiro 1980)-.

Florianópolis: Fundação José Boiteux. 1980-.

Publicação contínua

Resumo em português e inglês

Versão impressa ISSN 0101-9562

Versão on-line ISSN 2177-7055

1. Ciência jurídica. 2. Teoria política. 3. Filosoia do direito. 4. Periódicos.

I. Universidade Federal de Santa Catarina. Programa de Pós-graduação em

Direito

CDU 34(05)

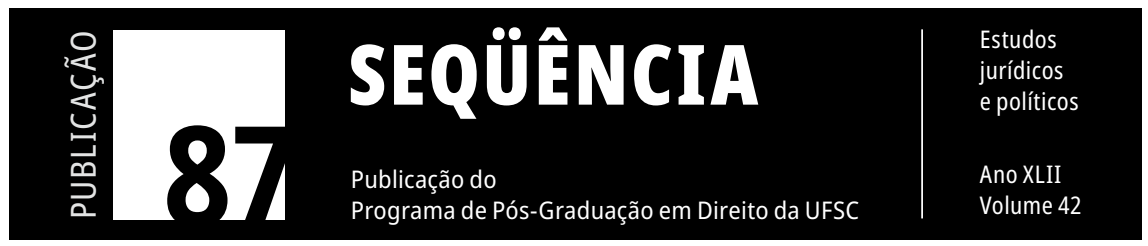




\title{
Restrictions on ultra-processed foods: challenge for compliance with World Trade Organization commitments
}

\author{
Restrições aos alimentos ultraprocessados: desafios para \\ observância dos compromissos da Organização Mundial do Comércio
}

Nicolas Cobo Romaní

Pontificia Universidad Católica de Chile, Santiago, Chile

Fábio Lins de Lessa Carvalho

Universidade Federal de Alagoas, Maceió, Brazil

ABSTRACT: The health problems, due to obesity and overweight (NCD), which cross the countries worldwide faces the challenge of applying different measures and restrictions, and at the same time raises the question whether these measures and restrictions are compatible with WTO and other commitments. Nowadays trade restrictions should not be justified based only on the industry process but rather in the ingredients and quality of those food contents, when the critical nutrients ingredients exceed a healthy threshold. The justification for the restrictive measures of the SPS agreement has been applied both in food labelling formats and in other formats, to address NDCs and whether similar restrictions can be applied to ultra-processed foods, such as those that have been applied in the past to the tobacco consumption, without breaking commitments.

KEYwORDS: Right to Food - Ultra-processed foods - Overweight and obesity Trade restrictions WTO.

RESUMO: Os problemas de saúde, decorrentes da obesidade e do sobrepeso (DCNT), que atingem os países do mundo, impõem o desafio de aplicar diferentes medidas e restrições e, ao mesmo tempo, levantam a questão se essas medidas e restrições são compatíveis com a OMC e outros compromissos. Hoje em dia, as restrições comerciais não devem ser justificadas com base apenas no processo da indústria, 
mas sim nos ingredientes e na qualidade desses conteúdos alimentares, quando os ingredientes de nutrientes críticos excedem um limite saudável. A justificativa para as medidas restritivas do acordo SPS foi aplicada tanto em formatos de rotulagem de alimentos, quanto em outros formatos, para abordar NDCs e se restrições semelhantes podem ser aplicadas a alimentos ultraprocessados, como aquelas que foram aplicadas no passado para o consumo de tabaco, sem quebra de compromissos.

PALAVRAS-CHAVE: Direito à alimentação - Alimentos ultraprocessados - Sobrepeso e obesidade - Restrições comerciais OMC.

\section{OVERWEIGHT AND OBESITY}

Overweight and obesity have become one of the biggest challenges for public health policies recent data show alarming growth of obesity rates by 2030: the US 47\%, Mexico 39\%, the United Kingdom 35\%, Canada 29\% (OCDE, 2017). The defiance of obesity and overweight that already reach 1.9 billion people worldwide, certainly requires different public policies ranging from prohibition, taxes, food labelling regulations, education, and promotion of physical activity and daily dietary guidelines. Different strategies are developed, although some of them could be disconnected and without proven efficacy, therefore its long-term effects must be demonstrated.

The Pandemic has spread into Latin America and other regions, particularly Chile became the country with the highest consumption of sugary drinks (MONTEIRO, 2019) and the expenditure on beverages is greater than that of legumes and fruits. According to the 2019 JUNAEB Nutritional Map, there is an alarming data that show "school-age children are $29 \%$ overweight, $17 \%$ obese, and $6 \%$ severely obese, with the prevalence of obesity in children under 6 years of age and an increase of $66.3 \%$ between 2005 and 2018, going from 7\% to 12\%" (JUNAEB, 2019). The said data only proves that several national campaigns and regulations are not yet successful in its main goal. 
There are several negatives health effects of Non-Communicable Disease (NCD), with an incidence in the development of various diseases such as cardiovascular, diabetes, hypertension, etc. Additionally, preliminary evidence shows that obesity and overweight maybe worsen the risk of patients " $[. .$.$] populations with a high prevalence$ of obesity, COVID-19 will affect younger populations more than previously reported." (Kass, 2020).

Poor nutrition due to excess food intake, is not limited to these regrettable and serious consequences but also extends negative externalities to large economic costs, an estimation of " $[. .$.$] the eco-$ nomic costs of obesity and overweight are projected to range from $0 \cdot 4 \%$ (Chile, derives from overweight and obesity) to $3 \cdot 1 \%$ (Ecuador, derives from a $2 \cdot 6 \%$ loss of GDP due to undernutrition and a $1.7 \%$ loss of GDP due to overweight and obesity) of GDP between 2015 and 2078. Additionally, undernutrition is projected to result in only a $0.03 \%$ GDP loss in Mexico and 0.06\% GDP loss in Ecuador during the same period" (KAss, 2020).

The Agenda for Sustainable Development and its Sustainable Development Goals (SDGs) focuses on 17 targets aiming reducing poverty and improving health, among those goals several of them related to trade and food quality, namely zero hunger, clean water, good health, responsible consumption and production, life below water and on land as well as climate action (UNITED NATIONS, 2021) are critical objectives in order to ensure proper access to safe food and reducing unnecessary restrictions to food trade. The world population affected by bad nutrition due to excess or lack of basic access to adequate food is already over 3 billion (FAO), therefore a coordinated action between several agencies i.e. FAO; OMS; WTO; UNICEF with formal commitments for joint actions

Closer collaboration between $\mathrm{UN}$ agencies such as WTO, WHO and FAO in relation with food trade commitments namely SPS, Codex Alimentarius as well as the relevant standard-setting organization food 
and IPPC for plant health for cooperation and better coordination, keeping international food standards.

Furthermore, Standards and Trade Development Facility (STDF) joined by same entities plus World Bank helping developing countries to implement standards enable better health protection and trade expansion.

The most significant goal for food and trade is SDG 2: End hunger, achieve food security and improved nutrition and promote sustainable agriculture (WTO, 2018), the comprehensive protection of food safe and security by a rules-based trading system firstly by Agriculture Agreements providing "a transparent, undistorted production and investment environment", removing all agricultural export subsidies together with all export measures with equivalent effect, in accordance with the mandate of the Doha Development Round. In order to reach SDG 2 is necessary the better compliance with SPS, "improving the predictability and transparency of the global agricultural trading system" and ensuring "access by all people to safe, nutritious and sufficient food all year around".

In the SDG 3, the goal falls TRIPS agreement through a balanced equilibrium of "certain minimum standards for the protection and enforcement of intellectual property rights" with a standards and "implementing trade facilitation measures in line with the WTO's Trade Facilitation Agreement, reducing tariffs on medicines, medical products and inputs to locally produced medicines, and supporting the convergence of regulations around common international standards which is promoted by the WTO's Technical Barriers to Trade Agreement" (WTO, 2018). Access to fewer obstacles and costs to medicines and innovations will benefit LDCs will certainly help to ensure healthy lives and promote well-being.

Some of the recommendations from WTO in order to achieve SDG are strengthen the multilateral trading system, keep reducing trade costs including through full implementation of the WTO's Trade Facilitation Agreement and ensure that non-tariff measures do not become barriers to trade, to this end better application of exis- 
ting standards and agreements' framework and disciplines ensuring access to "safe food available and can be traded without unnecessary barriers" (WTO, 2018).

Addressing concerns related to good quality food (safety and security), standards and composition, meanwhile, there are existing regulations under WTO, relevant Agreements on Sanitary and Phytosanitary Standards (SPS), Technical Barriers to Trade (TBT), additionally the Codex Alimentarius and the TRIPs should be duly considered and fulfilled. These commitments regulate the appropriate use of measures that, although the search for the legitimate objective of protecting the health and nutrition of the population, this does not imply that the authorities may establish discriminatory restrictions or that unduly affect trade.

Whether there is a real conflict between growing concerns on NCD and international trade, José Graziano da Silva from FAO, stated that, a great concern exists on high consumption of ultra-processed food, obesity and the need of rules and regulations that encourage the consumption of healthy and nutritious foods.

If the excess malnutrition pandemic were not convincing enough as a serious trend, furthermore obesity, undernutrition and climate change, together represent a Syndemic or synergy of epidemics, because they co-occur in time and place, interact with each other to produce sequelae, and share common underlying societal drivers (Boyd, 2019). Additionally, the current Covid-19 pandemic is also becoming part of the same Syndemic, preliminary data show increasing hunger, overweight and obesity, the final confirmation of real effects is open for future research.

\subsection{Ultra-processed foods}

We need to understand how food and industry system is configurated and interact, food can be classified into 4 groups: 1) unprocessed or minimally processed foods (e.g. fresh, frozen or dehydrated fruits 
and vegetables, grains and legumes, among others), 2) processed culinary ingredients (flours, oils, salt, sugars), 3) processed foods (breads, cheeses, salty foods, canned fruits, vegetables) and 4) ultra-processed ready-to-eat foods (snacks, pizzas, nuggets, drinks, etc.) (CAnella, 2014), these have some common characteristics such as: easy access, longer shelf life, greater flavour, lower cost, are easy to carry and have massive [and sometimes invasive] advertising, all of which contributes to an increasing trend in consumption, included total calories, percentages of daily food and family budget (C.A. Monteiro, 2013).

The consideration of a wide definition of ultra-processed foods (UPF) from nutritionist: formulations of ingredients, mostly of exclusive industrial use, typically created by series of industrial techniques and processes, this product also considers soft sugar drinks (MONTEIRO, 2019). Notably, UPF include the fractioning of whole foods into substances, chemical modifications of these substances, assembly of unmodified and modified food substances using industrial techniques such as extrusion, molding and pre-frying; use of additives at various stages of manufacture whose functions include making the final product palatable or hyper-palatable; and sophisticated packaging, usually with plastic and other synthetic materials (Monteiro, 2019). Many UPF create false impression of being healthy through industrial transformations enabling producers to make health claims (Monteiro, 2018).

The dietary quality and health provided by UPF has been highly questioned, a study published by FAO in 2019 (Monteiro, 2019) and using the NOVA classification, compares the nutrient contents that are associated with NCDs (sodium, sugar, energy density, saturated fat), as well as the possible existence of a negative correlation with protective nutrients (proteins, fibers, potassium, phytoestrogens) or micronutrients in a sample of eleven countries. A closer look is needed if, pursuant to the NOVA classification, based on nutrients rather than food, determines that UPF are arguably considered as food, their consumption is highly correlated with obesity and overweight (MARTINS, 
2013), due to their higher concentration of energy, high content of sugar, sodium and saturated fats and low content of nutrients such as protein and fibber. Moreover, according to Monteiro (Monteiro, 2013), it is not a question of persistent food harmful to health and if the consumption of this group were in small portions, however, the larger portion sizes and their ease of access, constitute it as a relevant factor of the obesity and overweight problem and should be connected with suppliers and the industry current system.

A study in Chile, has shown that intake of UPF represented $28.6 \%$ of total energy intake and contributed more than half of total added sugars intake and was closely associated with the consumption of UPF. Indeed, individuals with the highest consumption of UPF $(>47 \cdot 5 \%$ of energy intake) were three times more likely to exceed the $10 \%$ cut-off compared with those having the lowest consumption $(<9 \cdot 3 \%$ of energy intake) (CEDIEL, 2020), the presence of percentages greater than $10 \%$ of energy intake is observed in countries such as the USA, Brazil, Chile, Canada, Colombia, Australia and Mexico, of saturated fats. Furthermore, increases in high energy presence are also observed in UPF in countries such as Australia, Canada, Chile, Colombia and Mexico. UPF contribute more than 50\% of daily energy intake in high-income countries such as Canada and the USA, while in middle-income countries it is even less, such as Brazil (21.5\%), Mexico (29.8\%) and Chile (21.5\%) (PARra, 2019). The same study shows that among Ultra-Processed foods, the "largest contributor to total energy intake were industrial breads (5.0\%), sugary drinks (2.5\%), and packaged sweet and salty snacks (2.5\%). Another study shows that the contribution in calories by UPF is $58 \%$ in the USA, 48\% in Canada, 35.9\% in France and 56.8\% in the case of the United Kingdom (RAuber, 2018).

The evidence indicates that the diet based on UPF has a higher caloric intake, approximately $500 \mathrm{kcal} /$ per day (HALL, 2019) and a significant incidence of overweight and obesity in children, due to the presence of calories, sugars, fats, sodium, fibers and macronutrients, the 
aforementioned study implying that a reformulation of the products or the limitation of their consumption would be recommended for an obesity prevention strategy (HALL, 2019). Existing evidence has shown larger percentages overpassing recommendations of WHO that suggest to limit up to $10 \%$ intake of added sugar food in order to prevent overweight and other health problems (WHO, 2015).

Furthermore, an increased dietary contribution of UPF was associated with unhealthy nutrient content, with high dietary content of NCD-promoting nutrients and low content of NCD-protecting nutrients, evidence suggest that decreasing intake on UPF may help to achieve recommendations for a healthy diet (WHO, 2015).

Consistent evidence, repeatedly shows that UPF may be contributing to high rates of obesity in countries such as UK, Brazil, United States Canada and Spain (RAuber, 2020). Evidently, it's quite clear that UPF intake is associated with higher risk of overweight and obesity and an increase on UPF intake demonstrate to became more likely to present and increase in body mass index over time (SROUR, 2020). Obviously, not all UPF is unhealthy, instead a high intake of these food and beverage products is linked with poor diet quality, obesity and diet related NCD risk (LANCET, 2020).

In any case, we cannot place all expectations on the positive effects that reductions in critical nutrients can generate in food, since there is evidence in schools in Los Angeles that they do not have a decisive effect (COLEMAN, 2012), neither in the decrease in weight nor BMI reduction (Williams, 2013) or even an increase in the sale of these kind of food (Cullen, 2006). Governmental restrictions should consider that the attraction from processed and ultra-processed products offered in schools may even "increase the desire of students to want to consume them, since the prohibited product is seen as more appetizing and desirable" (FisCHER, 1999, p. 69).

An increase in the percentages of critical nutrients present in the daily diet from processed and UPF appears in the habits of students under 12 years old, evidencing 25.8\% of calorie intake (BAtalHa, 
2017). Therefore, what is being offered in restaurants in public schools must be reconsidered and modified, an experience in this sense was developed (Sustein, 2017), during the Obama administration by intervening in the distribution in which fresh food was offered. Otherwise access to salted and UPF in cafeterias, additionally, revisiting the school feeding program (PNAE), giving the facts that nowadays it is more likely the consumption of soft drinks, which are not prohibited in the public schools feeding program (RAYAnne, 2019).

Under the Law 20,606 of Chile, several restrictions were established on the sale of foods with critical nutrients in schools, as well as advertising, however, those regulations could not affect what happened outside the schools, therefore they ought to be more consistent and should not refrain from regulating what happens outside the school establishment (Duran-Aguero, 2017).

The cumulative effect is negative on family food consumption, since it increases the percentage amount destined to the consumption of less healthy foods within the ultra-processed group and the consumption of fresh and less processed foods is substituted, generating a change in habits that is consistent with what is observed in various countries of the region and that require special attention in evaluating the application of different alternatives of restrictions, whether in the dissemination, access, labelling or in encouraging the reformulation of food, accompanied by educational campaigns that promote better habits in school feeding, surpassing recommendations by FAO/WHO (Crovetto, 2012).

We need an more comprehensive approach and evaluate positions that suggest that the problem of poor nutrition that generates overweight and obesity, should be approached with a similar perspective to the fight against tobacco and alcohol, suggesting actions such as (Monteiro, 2019): eliminate all subsidies for agricultural inputs (corn) or meat intended primarily for UPF; taxation on the production and sale of ultra-processed products; marketing restriction and dissemination and incorporation of labels with visible warnings. 


\subsection{Comparative labelling experiences}

The food label of Chile incorporated some aspects that were novel, especially due to their simplified and highly visible packaging format, which transferred a real negative charge to companies on their image and even on their trademarks. It has anyhow been recognized by health organizations as a valuable tool in the fight to stop the advance of obesity, however, it is necessary to monitor for the long-term effects of its implementation, the results and the truly final efficacy on health.

Some counties adopted a traffic light labelling system, reporting on four main nutrients; e.g. United Kingdom: Since 2012 the UK Food Standards Agency and Ecuador: Health Regulations for the Labelling of Processed Foods for Human Consumption, in full force since 2014. Whilst other countries adopted a simplified labelling such as Peru approved a new regulation with similar characteristics that allows a comparative analysis (Legislative Decree 1304 and draft law 02036/2017), likewise, Uruguay approved in 2020 a new label (Decree 272/018); Mexico: in November 2019 issued a comprehensive new regulation including a similar black labels' system (Nom-51).

\subsection{Law 20.606 (Chile)}

Nutrition labelling seeks to guide consumers towards products that contribute to a healthy diet, providing them with information that is easy to interpret, allowing them to make better consumption decisions (Silva, 2016). Front labelling is one of the types of formats, and Chilean law has a severe standard,(SCRINIS, 2016) because black octagons are a clear and forceful sign regarding nutrients defined as critical to health, delivering to the consumer an unequivocal message.

The regulations also consider the protection of the school food environment by prohibiting the sale of "high in" foods in schools (pre-basic, basic and middle) (SiLva, 2016). Different studies have 
evaluated the effect of restricting UPF inside schools and how increases in sales of UPF can be seen in the self-service vending machines (Fischer, 1999 and Cullen, 2006).

Restricting less healthy foods to children reduces their consumption in those settings where the intervention is carried out, such as in schools. In many cases the reduction does not lead to improvements in the body mass index, because the consumption of less healthy foods would increase in unrestricted environments, this requires that the problem of substitution be addressed (SiLva, 2016).

Turning to UPF, the negative economic effects are already anticipated due to significant impact expected in GDP and economic growth due to health problems pursuant to ECLAC-WFP study, the existing trend, an estimation of economic cost of obesity and overweight are projected to range from $0 \cdot 4 \%$ (Chile) to $3 \cdot 1 \%$ (Ecuador) of GDP between 2015 and 2078 and from 0.6\% loss of GDP in Mexico (2014), in all cases represents grater loss than undernutrition impact (LANCET, 2020).

\subsection{Labelling problem and rationale}

International regulations have evolved towards convergence and standardization, influenced by the 1990 law, on the labelling of nutritional products and education in the United States NLEA (Nutrition Labelling and Education Act), in this regulation different agencies have participated (FDA, FSIS and USDA).

A simplified proposal based on warnings on black labels in Law 20,606 on the nutritional composition of food and its advertising, which modifies matters currently regulated by the Food Health Regulations, approved by Decree No. 977 of 1997 and Decree No. 115, 2003, from the Ministry of Health. It proposes a simple and precise nomenclature of the nutritional characteristics and the prohibition to commercialize within educational establishments of basic and secondary education those foods whose nutrients are considered excessive and establish fines for violators, according to articles 2 and 5 of Law 20,606. 
The industry has complained about the difficulties of reformulations, excessive costs and the short deadlines for making the changes, however, the challenge does no end up with reformulation of the industry if the final result is not healthier food " $[\mathrm{t}]$ his strategy is now even supported by some policy-makers outside industry. This is not a solution. Changing one problematic ingredient for another, such as less fat but more sugar, or sugar replaced by artificial sweeteners, does not make UPF healthy" (Monteiro, 2019).

\section{RESTRICTIONS COMPATIBLE WITH WTO}

The proliferation of different schemes and formats of FoP food labelling regulations either voluntary or mandatory, several of them in the similar simplified format of the Chilean food label, has risen the concern of consistency of existing standards and WTO commitment and a debate to foster further coordination, this is a convergence worry on WTO, FAO' officials and experts for the consideration of hazards to both health (food safety and security) and potential technical barriers to trade avoiding unnecessary trade cost and barriers.

In order to appreciate how restrictive measures compatible with the SPS and WHO agreements can be applied, those measures must be aimed in the protection of health, also comply with those agreements and avoid a potential breach of trade commitments before the WTO. In technical organizations such as WTO and WHO, valuable experiences can be gathered that enable us to identify the correct criteria and technical parameters that allow establishing restrictions based on public health needs, in order to avoid non-compliance with the obligations of international commitments assumed by the country in commercial and intellectual property matters.

Indeed, the agreements contemplate different restrictive measures in order to protect human health, animals, the environment, and misleading practices (labelling and packaging) should be avoided 
and in no case should they be more restrictive or with longer terms than what is necessary for compliance with national laws (WTO) (BozA, 2017).

Furthermore, not only restrictions shall be considered but also subsidies, in fact "massive subsidies of unhealthy food products, particularly where they fall within the categories of export subsidies" under Agreement on Subsidies and Countervailing Measures (SCM Agreement) and (in the case of agricultural products) the Agreement on Agriculture (Mitchell, 2010).

\subsection{TBT Committee}

The TBT agreement is subject to standards and conformity assessment procedures are non-discriminatory and not more trade-restrictive than necessary to fulfil a legitimate objective, including the protection of human health or safety, animal or plant life or health, or the environment (Friel, 2020).

In addition, we must bear in mind, whether the information provided by the country to trading partners should be timely, adequate and with a history of scientific support in the TBT Committee. There are also other formats that facilitate the comparison regarding the contents and their excesses, when considering the label of the Chilean regulations, the only possibility of comparison of similar products is in relation to the number of labels that the package has, different is the case of traffic light systems that include graduations of up to 5 levels (e.g., Australia, France).

TBT (Сово, 2018) are subject to principles, such as that unnecessary obstacles should not be established; nor be discriminatory, and should be based on national treatment, and that "[...] with respect to technical regulations, products imported from the territory of any of the Members should be treated no less favourably than that accorded to similar products of origin national and similar products originating in any other country" (art 2.1 TBT). The equivalence 
principle, by comparing technical regulations the same objective can be achieved; of transparency, and must be notified 60 days before the formal adoption of technical regulations and evaluation procedures, when "it may have a significant effect on the trade of other Members (art 5 TBT for 6)".

Some Chilean trade partners in the Committee (Mexico, EU, Argentina, Australia, Canada and Switzerland), expressed their concerns regarding the Chilean regulations, although they share the health objective invoked, expressed their concern that the measures decreed are compatible with the obligations of the TBT and TRIPs, since the agreements require that members must ensure that they do not establish unnecessary obstacles to international trade (art 2.4 TBT) and that they must be based on relevant standards (art 2.4 TBT), and there must be supporting scientific evidence to establish a threshold, the excess of which generates a health risk. (Сово, 2018)

Whilst it is not an ineffective or inappropriate means (for 285 $\mathrm{WT} / \mathrm{DS} 231 / \mathrm{AB} / / \mathrm{R}$ ) of the relevant standards (art. 2.4), in cases that deviate from international standards as the basis of technical regulations. Meanwhile the Codex Alimentarius includes significant provisions and guidelines for the use of healthy nutrition claims (CAC/GL 23-1997), the nutrition labelling guidelines (CAC/GL 2-1985) and the guidelines on property claims that may induce errors (CAC/GL 1-1979)". The parameter that we must use are the Codex guidelines and that are in harmony with nutrition policies (CAC/GL 23-1997) and supported by valid and scientific evidence.

The measures could imply unnecessary barriers to trade (Сово, 2018), existing alternatives for legitimate public health objectives, emphasizing that a low consumption of the same products does not generate health problems and also that the implementation deadlines were very restrictive. Mexico by his side, expressed doubts as to whether these measures comply with the principles of technical regulations (transparency, proportionality, scientific basis, and compliance with standards), as well as an eventual violation of TRIPs, requesting the 
revision and modification of standards and avoiding the use of instruments that were less restrictive (TBT Commitтee, 2014).

A communication was released by Mexican authorities in October 2019 at the TBT Committee (G/TBT, 2020), related to a draft amendment to Mexican Official Standard NOM-051-SCFI/SSA12010 in order to modify the existing labelling of pre-packaged food and non-alcoholic beverages for the submission of comments without formal consultant or modifications.

\subsection{Jurisprudence}

A legitim objective of life protection requires a non-discriminatory nor arbitrary, as well as, transparent measure to be fully in compliance with trade commitments; coherence with the health hazard; with a due risk assessment. Relevant jurisprudence from both Panel and Appellate Body has scrutinized, reviewed and interpreted the agreements and contributing with valuable elements to be considered when facing a measure that beyond the health ground shall not improperly affect international trade.

The local authorities' decisions have the recognition of a certain level of autonomy or Standard of review on the assessment granting a level of autonomy to national authorities. ${ }^{1}$

Trade agreements accept restrictive measures when they are supported on a scientific basis and an adequate assessment of risk " $R$ isk assessment", so as not to conform to arbitrary measures and to have a legitimate objective and there is a coincidence relationship between

\footnotetext{
"without conduct its own risk assessment, but examine and evaluate the evidence: "[W] e stress that in examining this case we did not attempt (nor are we, in our view, allowed) to conduct our own risk assessment or to impose any scientific opinion on Australia. We only examined and evaluated the evidence - including the information we received from the experts advising the Panel - and arguments put before us in light of the relevant WTO provisions and, following the rules on burden of proof set out above, based our findings on this evidence and these arguments Panel Report, Australia - Salmon (para 8.41)
} 
the measure and the risk assessed, likewise there must be a relationship between the measure and the risk assessment", represented in a "main trend of scientific opinion "and which must be based on risk assessments that have been taken into account (WT, 1998) and should be necessary to objectively protect life consistent with the health hazard; scientific justification; the measure should be the least restrictive to trade, with the less harmful possible alternative.

Regarding the risk assessment, Panel emphasizes that regarding risk assessment and the absence of Panel's mandate to make scientific risk comparison nor to state with scientific certainty, because " $t]$ he fact that one of the experts advising the Panel stated that "if you are trying to say which [of two products] is the most risky, then you need to know something about and possibly do a full assessment for [the other] product" and that "it would be sensible to assess that which you have prioritized initially to have the highest risk first, but until you have done the risk assessment, you actually cannot be sure you have got that right", does not change our position. Nor do we disagree with these statements. Indeed, for a scientist to say with scientific certainty that one product represents a higher risk than the other, there may be a need to have two, more or less, complete sets of data, including two risk assessments. And even on that basis a scientist would probably not be able to state with absolute certainty that one product is riskier than the other". (Panel, 2019).

\subsection{Precautionary Principle and its relevance}

The application of restrictions based on the precautionary principle can be justified when the relevant scientific evidence is "insufficient" (Article 5.7). ${ }^{2}$

2 "We would agree that the fact that a Member has decided to follow a precautionary approach could have a bearing on a panel's assessment of whether an SPS measure is "based on" a risk assessment as required by Article 5.1. We consider that if there are 
The discussion of the precautionary principle which "asserts that the burden of proof for potentially harmful actions by industry or governments rests on the assurance of safety and when there are threats of serious damage, scientific uncertainty must be resolved in favour of prevention", the practical functionality of the precautionary in the WTO system into question (FrIEL, 2020).

Measures adopted (provisionally) on the basis available pertinent information, "These four conditions set out in article 5.7, however, must be interpreted keeping in mind that the precautionary principle finds reflection in this provision, as the Appellate Body has emphasized: A Panel charged with determining, for instance, whether "sufficient scientific evidence" exists to warrant the maintenance by a Member of a particular SPS measure may, of course, and should, bear in mind that responsible, representative governments commonly act from the perspectives of prudence and precaution where risks of irreversible, e.g. life-terminating, damage to human health are concern" (Appellate Body, 2019). The risk related to hormones under Meat Products (Hormones) was not appropriate to the circumstances nor complied with SPS (Articles 5.1, 5.2), the precautionary principle invoked by UE could not be backed up with scientific evidence as affecting human

factors which affect scientists' level of confidence in a risk assessment they have carried out, a Member may in principle take this into account in determining the measure to be applied for achieving its appropriate level of protection from risks. Thus, there may conceivably be cases where a Member which follows a precautionary approach, and which confronts a risk assessment that identifies uncertainties or constraints, would be justified in applying (i) an SPS measure even though another Member might not decide to apply any SPS measure on the basis of the same risk assessment, or (ii) an SPS measure which is stricter than the SPS measure applied by another Member to address the same risk. However, even if a Member follows a precautionary approach, its SPS measures need to be "based on" (i.e., "sufficiently warranted" or "reasonably supported" by) a risk assessment. Or, to put it another way, such an approach needs to be applied in a manner consistent with the requirements of Article 5.1. Panel Report EC/ Approval and Marketing of biotech Products para. 7.3065 (quoted from WTO Analytical Index; SPS Agreement - article 5(Jurisprudence); December 2019) 
consequences in spite of estradiol-17 substances as potential cancer driver (DS26, 2009).

The SPS agreement does allow, under certain circumstances, to maintain health and safety measures "that result in a higher level of sanitary or phytosanitary protection through measures based on relevant international standards" (Article 3.3). The panel refrained from deciding whether the EU's estradiol-17 ban could be justified as such, saying the issue was moot as it was anyway WTO-inconsistent (due to the inadequacy of the risk assessment described above). Regarding the five hormones that the EU regulated on the basis of the precautionary principle, the panel concluded that Brussels did not adequately establish that it was "impossible to carry out a risk assessment within the meaning of the" SPS agreement.

Pursuant to article 5 of the SPS duly undertaken with the aim to protect health are justified insofar they also fulfil certain standards, "measures shall be based on assessment, as appropriate to circumstances, of the risk to human, animal or plant life or health" (article 5.1 SPS); additionally, the said assessment shall take into account "available scientific evidence" (article 5.2 SPS); "avoid unjustifiable distinction in levels" "if it result in discrimination or disguised restriction on international trade" (article 5.5 SPS); "minimizing negative trade effects", ensuring at the same time, that measures "are not more trade restrictive to achieve their respective level" of protection and "taking into account technical an economic feasibility" (article 5.6 SPS). All considerations are intended for unnecessary, unjustified (lack of scientific ground), discriminatory or excessive.

Although there are several significant assessments and considerations, indeed there should be a balance between the standard of review, the protections of health and the excessive disruption of trade our international trade has tools that may help on the risk assessment: an adequate standard of review, balancing scientific evidence; certain level of flexibility when evaluating the appropriate circumstances; the precautionary principle; minimizing negative trade effects, searching 
and appropriate level of protection although this should be addressed on a case to case basis, there are several cases and valuable jurisprudence under the DSU and specially the Appellate Body.

An alternative measure which is "significantly less restrictive to trade" than the sanitary measure contested. ${ }^{3}$ Therefore, a scientific process to determine that the measure under SPS is supported by a proper risk assessment with several factors in the said process under Article 5.2 of the SPS Agreement within a scientific process. The Appellate Body specified several factors to be considered facing the assessment of risks "available scientific evidence; relevant processes and production methods; relevant inspection, sampling and testing methods; prevalence of specific diseases or pests; existence of pest- or disease-free areas; relevant ecological and environmental conditions; and quarantine or other treatment".

3 "Canada argues that all four alternative options set out in the 1996 Final Report are significantly less trade restrictive. In its request for access to the Australian market, Canada examined in particular headless, eviscerated product and advocated that these products could be safely imported. We recall that the measure imposed by Australia (in effect, certain heat treatment requirements) prohibits the importation into Australia of fresh, chilled or frozen salmon, including the salmon products further examined. All four alternative options outlined above would allow imports of the salmon products further examined, albeit under specific conditions (e.g., the salmon products would have to be retail-ready fillets, eviscerated, headless or gilled, etc.). We consider that even imposing the most stringent of these specific conditions would still be significantly less restrictive to trade than an outright prohibition. As opposed to any of the other conditions, heat treatment actually changes the nature of the product and limits its use. Heat-treated salmon can obviously no longer be consumed as fresh salmon. Eviscerated, headless or filleted salmon, on the other hand, can either be consumed as fresh salmon or cooked salmon. We consider, therefore, that Canada has raised a presumption that all four alternatives outlined in the 1996 Final Report are "significantly less restrictive to trade" than the measure in dispute and that Australia has not rebutted this presumption Panel Report, Australia - Salmon (para 8.182) (quoted from WTO Analytical Index; SPS Agreement - article 5(Jurisprudence); December 2019)

4 "Factors to be Considered in Carrying Out a Risk Assessment. Article 5.2 of the SPS Agreement provides an indication of the factors that should be consider the assessment of risk. Article 5.2 states that: In the assessment of risks, Members shall consider all available scientific evidence; relevant processes and production methods; relevant inspection, sampling and testing methods; prevalence of specific diseases or pests; existence of pest- 


\subsection{Direct casualty between the substance and the possibility of adverse health effects ${ }^{5}$ : Cumulative elements}

With regard to article 5.6 the Appellate Body identified three separates elements and found that these elements applied cumulatively: "we agree with the Panel that article 5.6 and in particular, the footnote to this provision, clearly provides a three-pronged test to establish a

or disease-free areas; relevant ecological and environmental conditions; and quarantine or other treatment. The listing in Article 5.2 begins with "available scientific evidence"; this, however, is only the beginning. We note in this connection that the Panel states that, for purposes of the EC measures in dispute, a risk assessment required by Article 5.1 is "a scientific process aimed at establishing the scientific basis for the sanitary measure a Member intends to take". To the extent that the Panel intended to refer to a process characterized by systematic, disciplined and objective enquiry and analysis, that is, a mode of studying and sorting out facts and opinions, the Panel's statement is unexceptionable. However, to the extent that the Panel purports to exclude from the scope of a risk assessment in the sense of Article 5.1, all matters not susceptible of quantitative analysis by the empirical or experimental laboratory methods commonly associated with the physical sciences, we believe that the Panel is in error. Some of the kinds of factors listed in Article 5.2 such as "relevant processes and production methods" and "relevant inspection, sampling and testing methods" are not necessarily or wholly susceptible of investigation according to laboratory methods of, for example, biochemistry or pharmacology. Furthermore, there is nothing to indicate that the listing of factors that may be taken into consideration a risk assessment of Article 5.2 was intended to be a closed list. It is essential to bear in mind that the risk that is to be evaluated in a risk assessment under Article 5.1 is not only risk ascertainable in a science laboratory operating under strictly controlled conditions, but also risk in human societies as they actually exist, in other words, the actual potential for adverse effects on human health in the real world where people live and work and die. Appellate Body Report ECHormones, para 187 (quoted from WTO Analytical Index; SPS Agreement - article 5(Jurisprudence); December 2019)

5 "Indeed, we are of the views that, as a general matter, 'risk cannot usually be understood only in terms of the disease or adverse effect that ay result. Rather an evaluation of risk must connect the possibility of adverse effect with an antecedent or cause. For example, the abstract reference to the risk of cancer has no significance, in and of itself, under the SPS Agreement; but when one refers to the risk of cancer from smoking cigarettes, the particular risk is given context. Appellate Body Report Japan - Apples, footnote 372, para. 202 (quoted from WTO Analytical Index; SPS Agreement - article 5(Jurisprudence); December 2019) 
violation to article 5.6. As already noted, the three elements of this test under article 5.6 are that there is an SPS in which: (1) Is reasonably available taking into account technical and economic feasibility; (2) achieves the Member's appropriate level of sanitary or phytosanitary protection; and (3) Is significantly less restrictive to trade than the SPS measure contested" Therefore in order to have a consistent measure to article 5.6 "if there is no alternative available, taking into account technical and economic feasibility or if the alternative measure does not achieve Members' appropriate level of sanitary or phytosanitary protection or if it is not significantly less trade-restrictive, the measure in dispute would be consistent with the article 5.6" (Appellate Body, 2019).

Recent regulations in the format of FOP such as the voluntary Australian and New Zealand Health Star Rating, "the TBT Agreement states that Members 'shall give positive consideration to accepting as equivalent technical regulations of other Members, even if these regulations differ from their own, provided they are satisfied that these regulations adequately fulfil the objectives of their own regulations" (LAI, 2020).

\subsection{Australia - Tobacco Plain Packaging case}

It also seems necessary to consider, with respect to restrictive measures for the protection of health, the case of Australia (DS467) with respect to "[c]ertain measures related to trademarks, geographical indications and other generic packaging requirements applicable to products. of tobacco and the packaging of these products". These are restrictive measures that affect the use of trademarks and distinctive images for reasons of protection of the health of the population, in which some members submitted queries regarding Australian laws that "impose restrictions on trademarks and geographical indications, and other generic packaging requirements applicable to the products of tobacco" (Law No. 148 of 2011; Selection of Legislative 
Instruments of 2011, No. 263; Act No. 149 of 2011), thereby affecting the TRIPS commitments on property rights aspects, adopted in August 2018 by the DSB, the Panel found that in the allegations presented, it had not been demonstrated by the complainants that generic packaging measures were incompatible with agreements and commitments (Paris Convention and TRIPS Agreement), either because it was not demonstrated "that they compel market agents to carry out acts of unfair competition and that they mislead the qualities of the product"; "Restricting trade beyond a legitimate objective", taking into account the nature and seriousness of the risks, or inconsistent, among other considerations, with Australia's obligations to protect trademarks (Article 2, paragraph 2 of the TBT Agreement, paragraph 1 of art 1, among other norms referred to in the TRIPS Agreement).

With regard to the TRIPS agreement, members may adopt regulations and measures with the aim to protect public health and nutrition insofar those restrictions are consistent with TRIPs (Doha Declaration 2001), the Australia - Tobacco Plain Packaging case may be useful to illustrate that "[a]ny measure, legislative or otherwise, that interferes with trademark rights, which in the case of Australia includes both the right of use and the right of exclusion, would only be justified if it does not contravene the provisions of TRIPS, especially the Articles 17 and 20. Australia should comply its obligations under the TRIPS, unless the limitation of said right of "TRIPS plus" complies with the TRIPS Framework" (Marsoof, 2013).

Australian authorities' estimates that restrictive advertising measures have improved rates and that costs to industries are not significant, a decline in prevalence rates since 2012" data related to tobacco use and customs clearance, and household spending, all show continued declines in recent years. Dr. Chipty's model also estimated a 0.55 percentage point drop in smoking prevalence in Australia, more than 34 months after implementation, attributable to changes in packaging in 2012. (Department of Health Australian Governmen, 2016). 
In the case Australia-Tobacco Plain Packaging, if the special requirements encumber the use of a trademark 'in the course of trade' and 'unjustifiably', contrary to the arguments from Australia, the Panel proposed a new 'weighing and balancing' test to be applied on a case by case basis in identifying whether the use of a trademark in the course of trade has been unjustifiably encumbered by special requirements (para 7.2431). The three factors to be considered, according to the Panel, are: the nature and extent of the encumbrance, bearing in mind the legitimate interest of the trademark owner; the reasons for the special requirements; and whether those reasons sufficiently support the encumbrance (para 7.2430), leaving uncertainty for governments about the extent to which any given regulatory intrusion on trademark rights for a genuine public health or other policy reason is permitted under Article 20 (Voon, 2021).

Finally, Australian regulation was considered consistent with the TBT Agreement due to limited impact on trade and driven to the legitimate objective of protecting public health, being non-discriminatory, little impact on international trade and a sound public health basis (Voon, 2012).

We may agree with the need for better public policies in order to control and reduce UPF's industry both supply and demand similarly to those applied to reduce use of tobacco and consumption of alcoholic drinks. (Monteiro, 2019) To this aim international trade should undertake its responsibility for less healthy food and its trade policies hence responsible for the food environment, consumer behaviour and dietary patterns (FAO, 2018). An effective public policy to restrain excessive UPF intake, does not seem possible without coordinated action involving at least partial trade restrictions understanding "the true drivers-policies and trade agreements that support and actively facilitate the penetration of transnational food corporations into the global food system and national political inertia that prevents the implementation of strong regulations around taxation, marketing restrictions and nutrition labelling”(KHANDPUR, 2020, p. 54). 


\section{CONCLUSIONS}

Analyse the UPF and beverage limitations that nowadays in some counties contain restriction on sales in schools; food labels and a ban on advertising including the use of certain images intended for children, pose a growing challenge of complying with WTO commitments and evaluating whether they are appropriately limited to UPF.

If we accept the concept of an existing Syndemic (undernutrition, obesity and overweight and climate change plus Covid19), the said pandemic convergence requires a deeper review of the existing food system and its drivers, the role played by food industry, the global governance required and a perspective that incorporates the needs and concerns of all actors.

The application of restrictions (either TBT or SPS) shall comply with important standards and regulations, non-discriminatory, not more trade-restrictive than necessary to fulfil a legitimate objective (art 2.2 TBT), including human life and health, similarly with requirement from SPS measure shall also comply with international standards, a close consideration of these requirement should be balance carefully in order to face current challenges from our food system and, negative effects for our health (NCD), without affecting an existing equilibrium on international trade system.

Trade agreements can, and do interact with actions across the food system aimed at improving malnutrition and climate change, achieving a trade policy that promotes healthy and sustainable food system is not a straightforward technical matter (FRIEL, 2020).

The health problems, due to obesity and overweight, which cross the countries of the region and in other latitudes crosswise, require further research from the law experts that contributes to other disciplines for a systematic and comparative analysis of compliance in the implementation of compatible restrictions with WTO and other commitments, which has not yet challenged. 
Finally, the potential trade restrictions are justified based on the industry process but rather in the ingredients and quality of those food contents, when the nutritional critical ingredients exceed a healthy threshold, pursuant to international healthy recommendations.

The justification for restrictive measures of the SPS agreement has been invoked and this requires an analysis pursuant to the Chilean food labelling law and to include in the debate the necessity and convenience of applying similar restrictions to UPSs of those that in the past were applied to tobacco consumption.

\section{REFERENCES}

Althaf Marsoof, 'The Trips Compatibility of Australia's Tobacco Plain Packaging Legislation' (2013) 16 The Journal of World Intellectual Property. Appellate Body Report US/ Canada - Continued Suspension, para. 680 (quoted from WTO Analytical Index; SPS Agreement - article 5(Jurisprudence); December 2019).

Batalha, M.A., A.K. Teixeira, S.I. Oliveira, A. Miranda, F. de Sousa, L. Lopes y A.A. Moura (2017), "Processed and ultra-processed food consumption among children aged 13 to 35 months and associated factors", Cadernos de Saúde Pública.

Bernard Srour \& Mathilde Touvier "Processed and ultra-processed foods: coming to a health problem?” Pages 653-655 17 Aug 2020

Boyd A Swinburn,Vivica I Kraak,Steven Allender,Vincent J Atkins, Phillip I Baker,Jessica R Bogard,Hannah Brinsden, Alejandro Calvillo, Olivier De Schutter, Raji Devarajan, Majid Ezzati, Sharon Friel, Shifalika Goenka, Ross A Hammond, Gerard Hastings et al. The Global Syndemic of Obesity, Undernutrition, and Climate Change: The Lancet Commission report Elsevier. 2019.

Boza Martínez, Sofía and Guerrero, Mónica and Barreda, Rocío and Espinoza, Macarena, Recent Changes in Food Labelling Regulations in Latin America: The Cases of Chile and Peru (March 2017). SECO/WTI Academic Cooperation Project Working Paper Series 2017/04. 
Canella, D.S., R.B. Levy, A.P.B. Martins, R. Claro, J.-C. Moubarac, L.G. Baraldi, G. Cannon y C.A. Monteiro (2014), "Ultra-processed food products and obesity in Brazilian households (2008-2009)", Plos One, 9 (3).

C. A. Monteiro and others, 'Ultra-Processed Products Are Becoming Dominant in The Global Food System’ (2013) 14 Obesity Reviews.

Carlos A. Monteiro and Geoffrey John Cannon, 'The Role of The Transnational Ultra-Processed Food Industry in The Pandemic of Obesity and its Associated Diseases: Problems and Solutions' (2019) 10 World Nutrition.

Cass Sunstein, Paternalismo Libertario, Editorial Herder, 2017.

Cediel, G., Reyes, M., Corvalán, C., Levy, R., Uauy, R., \& Monteiro, C. (2020). Ultra-processed foods drive to unhealthy diets: Evidence from Chile. Public Health Nutrition.

Cobo Nicolás, 'Ley de Rotulación de Alimentos de Chile: ¿Traba Comercial o Protección de la Salud?’ (2018) 14 Revista de Direito Internacional.

Coleman, K.J., M. Shordon, S.L. Caparosa, M.E. Pomichowski y D. Dzewaltowski (2012), "The healthy options for nutrition environments in schools (Healthy ONES) group randomized trial: Using implementation models to change nutrition policy and environments in low income schools", The International Journal of Behavioral Nutrition \& Physical Activity.

Crovetto, M. y R. Uauy (2012), "Changes in processed food expenditure in the population of Metropolitan Santiago in the last twenty years", Revista Médica de Chile.

Cullen, K.W., K. Watson, I. Zakeri y K. Ralston (2006), “Exploring changes in middle-school student lunch consumption after local school food service policy modifications", Public Health Nutrition, 9.

DS26: European Communities - Measures Concerning Meat and Meat Products (Hormones).

Duran-Aguero, Samuel et al. Ley de Alimentos: una mirada de los nutricionistas y estudiantes de Nutrición y Dietética de Chile. Rev Esp Nutr Hum Diet [online]. 2017, vol.21, n.4 [citado 2020-09-22], pp.327-334. FAO, Trade and Food Security N 21, 2018.

Fernanda Rauber and others, 'Ultra-Processed Food Consumption and Chronic Non-Communicable Diseases-Related Dietary Nutrient Profile in The UK (2008-2014)' (2018) 10 Nutrients. 
Fisher, J. O. y L.L. Birch (1999), "Restricting access to palatable foods affects children's behavioral response, food selection, and intake", The American Journal of Clinical Nutrition.

Friel, S., Schram, A. \& Townsend, B. The nexus between international trade, food systems, malnutrition and climate change. Nat Food 1, 51-58 (2020).

Gyorgy Scrinis and Christine Parker, 'Front-Of-Pack Food Labelling and the Politics of Nutritional Nudges' (2016) 38 Law \& Policy.

Gustavo Cediel and others, 'Ultra-Processed Foods Drive to Unhealthy Diets: Evidence from Chile' [2020] Public Health Nutrition. G/TBT/N/ MEX/178/Add.9, 2020.

Hall, K. D., Ayuketah, A., Brychta, R., Cai, H., Cassimatis, T., \& Chen, K. Y. \& Fletcher, LA (2019). Ultra-processed diets cause excess calorie intake and weight gain: an inpatient randomized controlled trial of ad libitum food intake. Cell Metabolism, 30, 67-77.

Kass, D. A., Duggal, P., \& Cingolani, O. (2020). Obesity could shift severe COVID-19 disease to younger ages. Lancet (London, England), 395(10236), 1544-1545. https://doi.org/10.1016/S0140-6736(20)31024-2

Jessica C. Lai and Shmuel I. Becher, 'Front-Of-Pack Labelling and International Trade Law: Revisiting the Health Star Rating System' [2020] SSRN Electronic Journal.

Lancet Vol 935, January, 2020.

Mainstreaming Trade to Attain the Sustainable Development Goals WTO 2018 .

Mapa Nutricional JUNAEB 2019.

Martins, A.P., R. Bertazzi, R. Moreira, J.C. Moubarac y C.A. Monteiro (2013), "Increased contribution of ultra-processed food products in the Brazilian diet, 1987-2009)", Revista de Saúde Pública.

Mitchell, Andrew D. and Voon, Tania, Implications of the World Trade Organization in Combating Non-Communicable Diseases (May 1, 2010). Public Health, Vol. 125, pp. 832-839, 2011, University of Melbourne Legal Studies Research Paper No. 485.

Monteiro, C. y G.J. Cannon (2019), "The role of the transnational ultra-processed food industry in the pandemic of obesity and its associated diseases: Problems and solutions", World Nutrition, 10 (1). 
Monteiro, C., Cannon, G., Moubarac, J., Levy, R., Louzada, M., \& Jaime, P. (2018). The UN Decade of Nutrition, the NOVA food classification and the trouble with ultra-processing. Public Health Nutrition, 21(1), 5-17.

Neha Khandpur and others, 'Sociodemographic Factors Associated with The Consumption of Ultra-Processed Foods in Colombia' (2020) 54 Revista de Saúde Pública.

Obesity Uptade OCDE 2017 (https://www.oecd.org/health/health-systems/Obesity-Update-2017.pdf)

Panel Report, Australia - Salmon (para 8.126) (quoted from WTO Analytical Index; SPS Agreement - article 5(Jurisprudence); December 2019.

Parra, D.C., M.L. da Costa-Louzada, J.C. Moubarac, R. Bertazzi-Levy, N. Khandpur, G. Cediel y C.A. Monteiro (2019), "Association between ultra-processed food consumption and the nutrient profile of the Colombian diet in 2005”, Salud Pública Mexicana..

Rachel Nugent and Edward Fottrell, 'Non-Communicable Diseases and Climate Change: Linked Global Emergencies' (2019) 394 The Lancet.

Rauber, Fernanda \& Martinez Steele, Euridice \& Louzada, Maria Laura \& Millett, Christopher \& Monteiro, Carlos \& Levy, Renata. (2020). U1tra-processed food consumption and indicators of obesity in the United Kingdom population (2008-2016).

Rayanne, P., S. Noll, M. Noll, L.C. de Abreu, E. Baracat, E. Silveira e I.C. Esposito (2019), "Ultra-processed food consumption by Brazilian adolescents in cafeterias and school meals", Nature Scientific Reports.

Silva, F., Cobo, N., y M.A. Fellenberg (2016), "Propuesta de mejoras de la institucionalidad vigente para asegurar una alimentación saludable con énfasis en frutas y verduras frescas de calidad en las raciones entregadas por la Junaeb”, Cuaderno de Difusión CEIUC.

Tania Voon, Andrew D. Mitchell, Implications of WTO Law for Plain Packaging of Tobacco Products Public Health and Plain Packaging of Cigarettes: Legal Issues, Andrew Mitchell, Tania Voon and Jonathan Liberman, eds., Edward Elgar, UK, 2012, U of Melbourne Legal Studies Research Paper No. 554.

TBT Committee G/TBT/M/61, 2014.

United Nation, https://sdgs.un.org/goals (access May, 2021).

Voon Tania https://www.ip-watch.org/2018/07/03/wto-panel-australias-tobacco-plain-packaging-fact-dependent-analysis-trips-art-20/ (access May 7, 2021). 
Williams, A.J., W.E. Henley, C. Williams, J. Hurst, S. Logan y K.M. Wyatt (2013), "Systematic review and meta-analysis of the association between childhood overweight and obesity and primary school diet and physical activity policies", International Journal of Behavioral Nutrition \& Physical Activity. WTO Analytical Index; SPS Agreement - article 5(Jurisprudence); December 2019).

WHO Handbook Geneva, 2015.

$188 \mathrm{WT} / \mathrm{DS} 26 / \mathrm{AB} / \mathrm{R}$ and WT/DS48 /AB/R, 1998.

\section{NICOLAS COBO ROMANI}

Professor at School of Law at the Catholic University of Chile, Doctor of Law from the University of Salamanca and Master in International Trade from the University of Barcelona.

Professional address: School of Law at the Catholic University of Chile, Av Libertador Bernardo O’Higgins 340, Santiago, Región Metropolitana, Chile.

ORCID ID: https://orcid.org/0000-0001-5166-5131

E-MAIL:ncobo@hotmail.com

\section{FÁBIO LINS DE LESSA CARVALHO}

Professor at School of Law at the Federal University of Alagoas (Brazil), Doctor of Law from the University of Salamanca and Master in Public Law from the Federal University of Pernambuco. Professional address: Alagoas Law School, Av. Principal da UFAL - Cidade Universitária, Maceió - Alagoas, Brazil.

ORCID ID: https://orcid.org/0000-0002-3621-7290

E-MAIL: fabiolinslc@hotmail.com

Received: 21/06/2021

Accepted: 28/07/2021 